African Crop Science Journal by African Crop Science Society is licensed under a Creative Commons Attribution 3.0 Uganda License. Based on a work at www.ajol.info/ and www.bioline.org.br/cs DOI: https://dx.doi.org/10.4314/acsj.v27i1.3

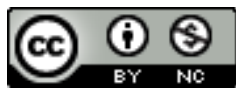

\title{
MINERAL FERTILISATION BY MICRODOSE: INCENTIVES FOR WIDESPREAD ADOPTION IN BURKINA FASO
}

\section{A. TRAORE, B. OUATTARA ${ }^{1}$, S. OUEDRAOGO ${ }^{2}$, A.J. YABI $^{3}$ and F. LOMPO $^{4}$}

Institute of Environment and Agricultural Research (INERA) / Natural Resource Management Program (GRN-SP) / CREAF of Kamboinse, 01 P. O. Box 476, Ouagadougou 01, Burkina Faso

${ }^{1}$ Institute of Environment and Agricultural Research (INERA)/ GRN-SP/Soil, Water, Plant

Laboratory / CREAF of Kamboinse, 01 P. O. Box 476, Ouagadougou 01, Burkina Faso

${ }^{2}$ Institute of Environment and Agricultural Research (INERA)/ GRN-SP/CREAF of Kamboinse, 01 P. O. Box 476, Ouagadougou 01, Burkina Faso

${ }^{3}$ University of Parakou, Benin, Faculty of Agronomy, Department of Agricultural Economics, P. O. Box 123 Parakou, Republic of Benin

${ }^{4}$ Institute of Environment and Agricultural Research (INERA)/ GRN-SP/Soil, Water, Plant Laboratory / CREAF of Kamboinse, 01, P. O. Box 476, Ouagadougou 01, Burkina Faso

Corresponding author: arahama.traore@yahoo.fr

(Received 13 June, 2018; accepted 21 February, 2019)

\begin{abstract}
Mineral fertilisation by microdosing has been tested in Burkina Faso since 2000 to increase the agricultural productivity of small farmers. In order to identify the determinants of its adoption, data were collected from a random sample of 180 women and 440 men in the provinces of Zondoma and Kourittenga in Burkina Faso; where the innovation was disseminated. The results of the Logit model showed that the determinants of adoption varied according to gender and production area. In Kourittenga, warrantage (inventory credit system) system determined the choice by women, whereas that by men depended on warrantage and dissemination tools. In Zondoma, in addition to access to information on mineral fertilisation by microdosing on which the choices of each type of farmer were dependent, education level and belonging to a farmer organisation determined the choice of men and women, respectively. These results challenged policy decision makers to strengthen socio-economic and institutional capacities for effective adoption of mineral fertilisation microdosing technique in order to sustainably improve the food situation of Sahelian small farmers.
\end{abstract}

Key Words: Gender, semi-arid, women

\section{RESUME}

La fertilisation minérale par microdose a été testée au Burkina Faso depuis 2000 en vue d'accroitre la productivité agricole des petits producteurs. Afin de promouvoir son adoption à grande échelle, des informations ont été collectées auprès d'un échantillon de 180 femmes et 440 hommes choisis de façon 
aléatoire dans les provinces du Zondoma et du Kourittenga où l'innovation a été diffusée afin d'identifier les déterminants de son adoption. Les résultats du modèle Logit indiquent que les déterminants d'adoption varient partiellement selon le genre et les zones. Au Kourittenga, le warrantage détermine le choix des femmes or celui des hommes dépend à la fois du warrantage et des outils de dissémination. Au Zondoma, en plus de l'accès à l'information, déterminant chez les deux types de producteur, le niveau d'instruction et l'appartenance à une organisation paysanne déterminent respectivement le choix des hommes et des femmes. Ces résultats interpellent les décideurs politiques à un renforcement des capacités socio-économiques et institutionnelles pour une adoption effective de la microdose afin d'améliorer durablement la situation alimentaire des producteurs sahéliens.

Mots Clés: Genre, femmes, fertilisation minérale, zone semi-aride, hommes

\section{INTRODUCTION}

Agricultural farms in Sub-Saharan Africa are characterised by low productivity farming systems, due to poor soils fertility and the unfavorable agro-climatic conditions induced by recurrent food insecurity crises (Ouédraogo et al., 2010). The incidence of natural factors was intensified by the extreme poverty faced by small farmers which limits their adaptability to climate change (Ouédraogo, 2005). Research activities carried out in the Sahelian area led to the development of inorganic fertilisation, through microdosing technique, in order to overcome the drastic pedoclimatic conditions of production and small farmers' low income. This low-cost fertilisation technique enables farmers to substantially increase crop yields, while protecting the environment (Palé et al., 2009; Bakayogo et al., 2011; Ouattara et al., 2018).

Combined with soil and water conservation techniques, microdosing technique improves the efficiency of fertiliser use and can lead to cereal grain yield increases from 30 to $60 \%$, or even more than $100 \%$ in some areas of West Africa (Aune et al., 2007; Tabo et al., 2007; FAO, 2011; Traoré et al., 2018). A large adoption rate of this technology could improve food security and break the vicious circle of small farmer poverty. Therefore, in Burkina Faso, several dissemination tools (demonstration tests, field days, training, local radio broadcasts, etc.) have been used by research and development projects to disseminate the technology. In addition, a community-based interest micro-credit system, called warrantage or inventory credit system, has been implemented by West African Research Institutes to promote the adoption of mineral fertilisation by microdosing in the Sahel (Sogodogo et al., 2014; Ouattara et al., 2018). However, significant studies related to suitable warrantage system and to the efficacity of dissemination tools use are lacking. Moreover, it is difficult to limit the matter of mineral fertilisation by microdosing adoption to these two factors. Such an approach could not be generalised to all farmers groups, since women and men farmers do not yet have the same socio-economic characteristics. In Burkina Faso, women, although represent 52\% of the population, are lacking in land ownership rights, and have limited access to extension services (MPF, 2012).

Factors which influence the decision to adopt technologies in agriculture are mainly those related to the individual farmers characteristics (socio-economic and institutional) and those related to the specificity of the innovations (Batz et al., 2003). Asfaw and Adamassie (2004) showed that the decisive factors for inorganic fertiliser adoption were of socio-economic and institutional in nature. Therefore, the determinants of mineral fertilisation by microdosing adoption would depend on farmers socio-economic and institutional conditions, insofar as they are aware of the level of soil degradation and the importance of inorganic fertilisers use to 
sustain farming system (Ouedraogo et al., 2010).

This paper aims to analyse the determinants of the adoption of microdosing in Burkina Faso in order to guide agricultural policies towards actions allowing a large-scale adoption of this innovation.

\section{MATERIALS AND METHODS}

Study area. The study was carried out on two sites located at the northern (Zondoma Province) and central (Kourittenga Province) parts of the north Sudanian zone of Burkina Faso. The province of Zondoma is situated between $12^{\circ} 38^{\prime}$ and $14^{\circ} 18^{\prime}$ north latitude and $1^{\circ} 33^{\prime}$ and $2^{\circ} 55^{\prime}$ west longitude. Annual rainfall of this site is variable $(500-800 \mathrm{~mm})$. The province of Kourittenga lies between $11^{\circ} 48^{\prime}$ and $12^{\circ} 34^{\prime}$ north latitude and $0^{\circ} 20^{\prime}$ and $0^{\circ}$ $38^{\prime}$ 'west longitude. The annual rainfall varies between 600 and $900 \mathrm{~mm}$.

Most soils are tropical ferruginous, which are similar to Luvisol and Lixisol according to the classiûcation of the World Reference Base (WRB) for soil resources (FAO, 2006). They represent approximately 39\% of the soils of Burkina Faso and are poor in phosphorus and nitrogen (Ouattara et al., 2018). Therefore, they are demanding for low cost and efficient mineral fertilisation to enhance their production capacity.

In both areas, men's farming systems are dominated by sorghum; while cowpea is the main crop for women. The province of Kourittenga is the real economic hub; trade and warrantage system are much developed. In Zondoma, on the other hand, farming systems are very much oriented towards agropastoralism, with a large production of organic fertiliser.

Data collection. Data were collected through individual farmers surveys in seven villages where mineral fertilisation by microdosing was disseminated. Survey using an individual questionnaire were conducted on two random sample plots in each province, one set of 90 women and another of 220 men.

Theoretical approach to the analysis of determinants for agricultural innovations adoption. According to Abadi-Ghadim et al. (2005), the adoption of an innovation is a dynamic decision-making process, involving the acquisition of information and know-how by the farmers, which changes according to their management capacities, their preference for the risks, their perception of profitability and risk of innovation. Several authors (Ransom et al., 2003; Abadi-Ghadim et al., 2005; Shiferaw et al., 2008; Kam, 2013) attempted to define adoption, with the conclusion that adoption of a technology depends on its own characteristics, farmers socio-economic conditions and those of the production environment. As a result, the factors influencing the adoption decision by farmers are generally classified into two groups: those related to the individual characteristics of farmers and those related to the intrinsic characteristics of the innovations (Batz et al., 2003). Factors related to farmer conditions are age, farm size, education level, farmer's experiences, extra-agricultural income, information, training, and membership of a social organisation, personal attitudes to changes and risks. The characteristics of the technology are mainly profitability, market orientation, investment, complexity and relative risk (Fagbémissi et al., 2002; Abadi-Ghadim et al., 2005; Shiferaw et al., 2008; Blazy, 2011). From these theories, for a technology to be adopted in a rural area, it must not only be adapted to the agro-ecological and socioeconomic conditions that characterise each production environment, but also respond to the sometimes subjective preferences of the farmers (Shiferaw et al., 2008; Ntsama Etoundi et Pedelahore, 2010; Blazy, 2011 ; Kam, 2013) ).

In this article, adoption is defined as the decision to choose microdose technology. As for the analysis of the determinants, it deals 
with factors related to socio-economic and institutional characteristics of the farmers insofar as the effectiveness of mineral fertilisation by microdosing, as well as its adaptation to the agro-ecological and climatic context of the Sahel, were demonstrated by many authors (Aune et al., 2007; Tabo et al., 2007; Palé et al., 2009).

Choice of the theoretical analysis model. This study highlights the relationship between the socio-economic and institutional characteristics of farmers, and their decision to adopt microdosing. The analysis of choices is based on the principle of rationality, and more precisely on the theory of maximisation of utility. This theory states that, depending on its socio-economic and demographic characteristics, a rational farmer will adopt a given agricultural technology if the utility associated with this technology exceeds that of the old practice (Abadi-Ghadim et al., 2005; Shiferaw et al., 2008). Designating this by $U i j$, the utility which farmer $i$ hopes to obtain from the use of the technique $j$, he will use this technology, if $U i j>U i O$. UiO being the utility derived from the old practice.

Among the three models (linear probability, Logit and Probit) often used to analyse the adoption decision when the decision variable is dichotomous (Asfaw and Admassie, 2004; Adéoti et al., 2002), the Logit model is the most suitable for small size samples. Thus, a logistic regression model was estimated in this study in order to analyse the influence of socioeconomic and institutional factors on farmers' adoption decision. Where $Y$ is the dependent variable (adoption decision), it takes the value 1 if the farmer adopts the mineral fertilisation by microdosing, and 0 if not.

From the theories, the decision to adopt an agricultural innovation intervenes only when the combined effect of explanatory factors reaches a value from which the farmer agrees to use or to adopt the innovation. Where $Y i *$ is the latent (unobservable) variable corresponding to the cumulative effect of the farmer $i$ explanatory variables:
$Y_{i}^{*}=\beta^{\prime} X_{i}+\mu_{i}$

Where:

$\mathrm{Xi}$ is a matrix of socio-economic and institutional variables (Table 1) that may influence the decision of the farmer $i$ to adopt mineral fertilisation by microdosing; $\beta$, , a vector of the parameters â associated with the explanatory variables and ì, the error term. $i=\{1, \ldots \ldots, n\} ; n$ being the size of the sample. $Y i$, the dependent variable associated with the adoption of microdosing by the farmer $i$ can take two values (one or zero) according to the value of $\mathrm{Y}^{*}$ :

$$
\left\{\begin{array}{lll}
Y_{i}=1 & \text { si } & Y_{i}^{*}>0 \\
Y_{i}=0 & \text { si } & Y_{i}^{*}<0
\end{array}\right.
$$

Where:

$P i$ is the probability of adoption that the Logit distribution associates with farmer $i$, and $\mathrm{F}$ a function of the logistic distribution; the logistic theoretical model making it possible to explain the adoption decision by $p$ explanatory variables according to Rouvière (2008) is as follows:

$$
\begin{aligned}
& P_{i}=P\left(Y=1 \mid X_{i}\right)=F\left(X_{i} \beta^{\prime}\right)= \\
& \frac{e^{X_{i} \beta^{\prime}}}{1+e^{X_{i} \beta^{\prime}}}=\frac{1}{1+e^{-X_{i} \beta^{\prime}}}
\end{aligned}
$$

Or

$$
\operatorname{LogitP}_{i}=X_{i} \beta^{\prime}
$$

Specification of variables. To analyse the determinants of adoption of mineral fertilisation by microdosing, the variables recorded in Table 1 were considered in the logistic regression model. These included age, household size, level of education, membership 
TABLE 1. Explanatory variables introduced into the Logit model for the study of microdosing determinants adoption in Burkina Faso

\begin{tabular}{|c|c|c|c|}
\hline Variable & Type of variable & Description of variables & Expected sign \\
\hline Age of farmers (Age) & Quantitative variable & It corresponds to the number of years of the farmer & Negative \\
\hline Household size (Size) & Quantitative variable & This variable is the number of people living in the household & Positive \\
\hline Access to micro-credit (Warran) & Qualitative variable & $\begin{array}{l}\text { Participation of the farmer in warrantage. It takes the value } 1 \\
\text { if yes and } 0 \text { if no }\end{array}$ & Positive \\
\hline Access to information on microdose (Info) & Qualitativevariable & $\begin{array}{l}\text { It takes } 1 \text { if the farmer got the information through a } \\
\text { dissemination tool and } 0 \text { if no }\end{array}$ & Positive \\
\hline Level of education (INS) & Qualitativevariable & $\begin{array}{l}\text { Variable characterising the instruction or literacy of the farmer. } \\
\text { It takes the value } 1 \text { if yes and } 0 \text { if no }\end{array}$ & Positive \\
\hline Membership of a farmer organization (Op) & Qualitativevariable & $\begin{array}{l}\text { It takes the value } 1 \text { if the farmer belongs to a farmer organisation } \\
\text { and } 0 \text { if no }\end{array}$ & Positive \\
\hline Tenure (Tefon) & Qualitativevariable & $\begin{array}{l}\text { Land tenure of the farmer. It takes } 1 \text { if they own their field and } 0 \\
\text { if no }\end{array}$ & Positive \\
\hline Non-agricultural activities (Secon) & Qualitativevariable & $\begin{array}{l}\text { Represents the activities that the farmer conducts in addition to } \\
\text { agricultural production (trade, breeding, etc.). It takes } 1 \text { if the } \\
\text { farmer carries on an activity in addition to agricultural production } \\
\text { and } 0 \text { if no }\end{array}$ & Positive \\
\hline
\end{tabular}


of a farmer organisation, access to information through a dissemination tool, land tenure, and off-farm activities. All the variables reported in Table 1 were considered in the model estimation, with the exception of the household size variable which was considered only in the estimation of the male model to test the hypothesis that the need for labour would be a constraint to the adoption of inorganic fertiliser by microdosing.

Age. The number of years of the farmer should negatively influence the adoption of mineral fertilisation by microdosing. According to Zegeye et al. (2001), the adoption of new technologies requires a certain level of risk associated with the farmer decision. Young people are likely to take more risk than older farmers (Nkamleu et Coulibaly, 2000; Ouédraogo et al., 2010; Yabi et al., 2016 ).

Size. The size of the household should positively influence the decision to adopt mineral fertilisation by microdosing, by men as its application requires additional work. The application of fertilisers in microdose is to sow small doses of fertiliser near the young plant, which requires additional labour (work) compared to conventional method of fertilisation where the fertiliser is not sown. Therefore, the larger the household, the higher the probability of adopting the innovation.

INS. Represents the level of education of the farmer. Considered to be decisive in the adoption of technologies, this variable should evolve in synergy with microdosing adoption because it can increase the ability of farmer and facilitate the appreciation of the agronomic and economic benefits of innovations.

Info. Dissemination tools play a key role in the transfer of innovation in the farmer's environment by informing farmers about the characteristics of the technology and the benefits associated with its adoption (Sidibé, 2005). A positive influence of this variable on the probability of adoption of mineral fertilisation by microdosing is then expected. In this study, these tools correspond to training, demonstration tests, field days and radio broadcasts.

Op. The fact that a farmer belongs to a farmer organisation positively influence the adoption of microdosing. According to Zarafi et al. (2002), this variable offers a number of benefits to farmers such as access to credits, inputs and training and thus plays a positive role in encouraging adoption.

Secon. The practice of a secondary activity, such as small trade and livestock should positively influence the adoption of mineral fertilisation by microdosing insofar as this innovation involves a cost. These activities form an integral part of farms' counts (Roesch, 2007). Therefore, the income from the secondary activity could support the costs generated by the application of mineral fertilisation by microdosing.

Tefon. This variable represents land tenure. It expresses whether a farmer is or not a land owner. Land tenure could be an important factor in the adoption of microdosing as this technique is an intensification practice, which can be profitable over two years because of the carry-over effect of fertilisers. As a result, land owners have the certainty of making their investment profitable, unlike non-land owners who can be dispossessed of land at any time. Microdosing is an intensification practice; the farmer will be more willing to invest in his own field because of the carry-over effect of fertilisers.

Warran. Access to warrant credit is expected to favor mineral fertilisation by microdosing adoption as it helps to secure farmer income, to support income-generating activities, and to facilitate bulk-purchasing of inputs (Sogodogo et al., 2014; Ouattara et al., 2018). 
This variable was supposed to evolve in the same direction as the adoption of microdosing.

\section{RESULTS}

Socio-economic characteristics of farmers. The results of the descriptive analyses showed that the rate of microdosing adoption depended on study sites and gender issue.

Kourittenga site. In Kourittenta, microdose adoption rates were 19 and $45 \%$, respectively, for women and men (Table 2). The average age of men was 45 against 43 years for women. More than half of the sample from Kourittenga province (51\% of women and $60 \%$ of men) received information on microdosing technique through dissemination tools. Warrantage system was practiced by $20 \%$ of men and $30 \%$ of women. The average household size in the province was 12 members. About $96 \%$ of farmers in the area carried out others lucrative activities like petty trading, breeding, various services. The education rate was low among women, about $9 \%$. On the other hand, $47 \%$ of men, are educated or literate. The rates of household head belonging to a farmer organisation are 39 and $60 \%$, respectively, for the men and women in Kourittenga. Only $3.3 \%$ of women are land owners, compared to $99 \%$ of men.

Zondoma site. In Zondoma province, microdosing technique was practiced by $43 \%$ of women and $50 \%$ of men (Table 3 ). The average age varied between 44 and 48 years depending on the type of producer. Information on microdosing was received by $47 \%$ of women and $48 \%$ of men, through a dissemination tool. The level of literacy in Zondoma was 6 and 30\%, respectively, for women and men head household. The average household size in the province was 10 members. As in Kourittenga, the percentage of land owners' women was low (6\%) compared to $97 \%$ of men. The secondary activities were done by $71 \%$ of women and $95 \%$ of men. The rate of belonging to a farmer organisation varied between 25 and 38\%, according to gender. The warrantage system is not practice in Zondoma.

Econometric analyses. The results of the Logit model estimate showed that the variables introduced into the model contributed to explain globally, the adoption decisions of women and men because the model was significant at the $1 \%$ threshold (Tables 4 and

TABLE 2. Socio-economic characteristics of farmers in Kouritenga province in Burkina Faso

\begin{tabular}{lrr}
\hline Variables & Women & Men \\
\hline Microdosing adoption rate (\%) & 18.9 & 45 \\
Average age (years) & 43 & 46 \\
Proportion of farmers who received information through formal dissemination & 51 & 60 \\
tools (\%) & 30 & 20 \\
Rate of participation in warrantage (\%) & - & 12 \\
Average household size & 95.6 & 96 \\
Non-agricultural activity rate (\%) & 8.9 & 47 \\
Education rate (\%) & 60 & 39 \\
Proportion of research units membership of a farmer organisation (\%) & 3.3 & 99 \\
Land tenure (\%) & 90 & 220 \\
N (sample size) & &
\end{tabular}

Source: Survey data 2014 
TABLE 3. Socio-economic characteristics of farmers in Zondoma province in Burkina Faso

\begin{tabular}{lrr}
\hline Variables & Women & Men \\
\hline Microdosing adoption rate (\%) & 43.3 & 50 \\
Average age (years) & 44 & 48 \\
Proportion of farmers who received information through formal dissemination & 47 & 48 \\
tools (\%) & & \\
Rate of participation in warrantage (\%) & 0 & 0 \\
Average household size & - & 10 \\
Non-agricultural activity rate (\%) & 71.1 & 95 \\
Education rate (\%) & 6 & 30 \\
Proportion of research units membership of a farmer organisation (\%) & 38 & 25 \\
Land tenure (\%) & 6 & 97 \\
N (sample size) & 90 & 220 \\
\hline
\end{tabular}

Source: Survey data 2014

5). However, the value of the determination coefficient, as well as the individual contribution of the variables to the explanation of the adoption, was dependent on the areas and the type of farmer.

Kourittenga site. In the province of Kourittenga, the Hosmer-Lemeshow test indicated that the Logit model was adequate because the probability values of Chi squared of 0.531 and 0.355 , respectively for women and men, were greater than 0.05 at eight degrees of freedom. The model predicted at 70.5 and $81.1 \%$ the values observed, respectively for women and men. The variations in the adoption probability were explained at 37.2 and $39.5 \%$, respectively for women and men, by the exogenous variables of the model. While the coefficients of the variables, Warran and Info, were significant and positive for men, it was only that of Warran that was significant for women at the $1 \%$ threshold. The significant and positive coefficient of the warrantage advantage shows that the probability of adoption of the microdose by men and women of the Kourittenga increases with their access to warrantage credit. In other words, farmers whose access to credit is more likely to adopt microdosing technique than those which cannot access to microcredit. As the coefficient of the access to information variable is also significant and positive for men, this variable enhances the probability of women who adopt microdosing technique.

Thus, warrantage and access to information individually and positively explained the decision to adopt mineral fertilisation by microdosing among men. On the other hand, the choice of women was influenced only by warrantage system (Table 4). In Kourittenga, access to warrantage and information are the determinants of microdosing technique adoption. The other variables introduced into the model had no significant effect on the probability of adoption of different types of farmer (Table 4).

Zondoma site. The results of the Logit model estimate in Zondoma province are shown in Table 5. The Hosmer-Lemeshow test showed that the Logit model fitted well at the 5\% threshold for both women and men. This was because the values of the probability of Chisquare at eight degrees of freedom were 0.27 and 0.33 , respectively, for women and men. The model predicted at 82 and $89.5 \%$ the values observed, respectively, for women and men. The variation in the adoption decision for women and men was respectively 53.6 and 
TABLE 4. Results of the Logit model estimate in Kourittenga province in Burkina Faso

\begin{tabular}{|c|c|c|c|c|c|c|c|c|c|c|}
\hline \multirow[t]{3}{*}{ Variables } & \multicolumn{10}{|c|}{ Dependent variable $=\mathrm{Y}=$ Adoption } \\
\hline & \multicolumn{5}{|c|}{ Women } & \multicolumn{5}{|c|}{ Men } \\
\hline & $\beta$ & S.E. & $\begin{array}{c}\text { Wald Khi } \\
\text { square }\end{array}$ & $\begin{array}{r}\text { Pr }>\text { Khi } \\
\text { square }\end{array}$ & $\operatorname{Exp}(\beta)$ & $\beta$ & S.E. & $\begin{array}{c}\text { Wald Khi } \\
\text { square }\end{array}$ & $\begin{array}{r}\text { Pr }>\text { Khi } \\
\text { square }\end{array}$ & $\operatorname{Exp}(\beta)$ \\
\hline Constant & -1.759 & 2.354 & 0.559 & 0.455 & 0.172 & -1.666 & 1.981 & 0.708 & 0.4 & 0.189 \\
\hline Age & -0.016 & 0.034 & 0.212 & 0.645 & 0.985 & 0.018 & 0.014 & 1.824 & 0.177 & 1.018 \\
\hline Size & - & - & - & - & - & 0.021 & 0.025 & 0.718 & 0.397 & 1.021 \\
\hline Warran & $2.089 * * *$ & 0.786 & 7.073 & 0.008 & 8.078 & $2.209 * * *$ & 0.517 & 18.272 & 0.000 & 9.107 \\
\hline Info & 0.747 & 0.758 & 0.972 & 0.324 & 2.111 & $1.981 * * *$ & 0.376 & 27.734 & 0.000 & 7.251 \\
\hline Op & 0.481 & 0.959 & 0.251 & 0.616 & 1.618 & 0.184 & 0.364 & 0.256 & 0.613 & 1.202 \\
\hline Secon & -0.978 & 1.509 & 0.42 & 0.517 & 0.376 & -0.792 & 0.885 & 0.797 & 0.372 & 0.454 \\
\hline INS & 0.529 & 0.991 & 0.285 & 0.594 & 1.697 & 0.514 & 0.348 & 2.182 & 0.14 & 1.673 \\
\hline Tefon & 0.800 & 1.328 & 0.363 & 0.547 & 2.226 & -0.871 & 1.578 & 0.305 & 0.581 & 0.419 \\
\hline Hosmer-Lemeshow Test & & & & 0.531 & & & & & 0.355 & \\
\hline -2log- likelihood & 63.600 & & & & & 225.474 & & & & \\
\hline $\mathrm{R}$-squared $\left(\mathrm{R}^{2}\right)$ & 0.372 & & & 0.001 & & 0.395 & & & & 0.000 \\
\hline Khi-squared & 23.63 & & & & & 76.88 & & & & \\
\hline Statistical prediction & 81.1 & & & & & 70.5 & & & & \\
\hline
\end{tabular}


TABLE 5. Results of the Logit model estimate in Zondoma province in Burkina Faso

\begin{tabular}{|c|c|c|c|c|c|c|c|c|c|c|}
\hline \multirow[t]{3}{*}{ Variables } & \multicolumn{10}{|c|}{ Dependent variable $=\mathrm{Y}=$ Adoption } \\
\hline & \multicolumn{5}{|c|}{ Women } & \multicolumn{5}{|c|}{ Men } \\
\hline & $\beta$ & S.E. & $\begin{array}{c}\text { Khi } 2 \text { de } \\
\text { Wald }\end{array}$ & Pr $>$ Khi2 & $\operatorname{Exp}(\beta)$ & $\beta$ & S.E. & $\begin{array}{c}\text { Khi } 2 \text { de } \\
\text { Wald }\end{array}$ & Pr $>$ Khi 2 & $\operatorname{Exp}(\beta)$ \\
\hline Constant & $-2,135$ & 1,607 & 1,765 & 0,184 & 0,118 & $-0,555$ & 1,714 & 0,105 & 0,746 & 0,574 \\
\hline Age & 0,007 & 0,034 & 0,04 & 0,841 & 1,007 & 0,025 & 0,02 & 1,554 & 0,212 & 1,025 \\
\hline Size & - & - & - & - & - & 0,008 & 0,051 & 0,026 & 0,871 & 1,008 \\
\hline Info & $2,223 * * *$ & 0,637 & 12,184 & 0,000 & 9,233 & $4,983 * * *$ & 0,59 & 71,226 & 0,000 & 145,932 \\
\hline Op & $1,947 * * *$ & 0,616 & 9,98 & 0,002 & 7,007 & 0,124 & 0,676 & 0,034 & 0,855 & 1,132 \\
\hline Secon & $-0,675$ & 0,686 & 0,968 & 0,325 & 0,509 & $-1,587$ & 1,053 & 2,272 & 0,132 & 0,205 \\
\hline INS & 1,056 & 1,224 & 0,743 & 0,389 & 2,874 & $1,995^{* * *}$ & 0,637 & 9,793 & 0,002 & 7,349 \\
\hline Tefon & 1,190 & 1,139 & 1,092 & 0,296 & 3,287 & $-1,957$ & 1,186 & 2,72 & 0,099 & 0,141 \\
\hline Hosmer-Lemeshow Test & & & & 0,274 & & & & & & 0,334 \\
\hline -2log-vraisemblance & 77,251 & & & & & 128,25 & & & & \\
\hline $\mathrm{R}$-squared $\left(\mathrm{R}^{2}\right)$ & 0,536 & & & 0,000 & & 0,736 & & & & 0,000 \\
\hline Khi-squared & 45,910 & & & & & 176,72 & & & & \\
\hline Statistical prediction & 82,2 & & & & & 89,5 & & & & \\
\hline
\end{tabular}

Warran = Warrantage Info = Access to information; Po = membership of a peasant organization; Secon = Secondary activity INS = level of education; Tefon $=$ land tenure. $* * *$ : Significant value at $1 \% ; * *$ Significant value at $5 \%$; Significant value at $10 \%$ 
$73.6 \%$, explained by those of the explanatory variables. In this province, the coefficients of the variables "access to information on innovation (Info)" and "level of education (INS)" were significant and positive for men. This shows that the variables access to information on innovation and educational level increase the probability of adoption of microdose among men. In other words, a man with access to information has a higher probability of adopting the microdose compared to the one without information. In the same logic an educated farmer has a higher probability to adopt microdose technique than an uneducated or illiterate one.

Among women, in addition to the coefficient of the variable Info, that of the variable "membership of a farmer organisation $(O p)$ " was significant and positive. Among women, in addition to the coefficient of the variable 'access to information', which is significant at the $1 \%$ level, that of the variable 'membership of farmer organisation' is significant and positive at the $1 \%$ level. This shows that variables 'access to information' and 'membership of farmer organisation' improve the probability of adoption of microdose by women. In other words, women with access to information are more likely to adopt microdosing technique. Also, women members of a farmer organisation are more likely to adopt microdosing technique.

Therefore, the variables "access to information" and "educational" level' positively influenced the probability of adoption of microdosing by men. On the other hand, the choice of women was positively influenced by the variables 'access to information' and 'membership of farmer organisation'. In Zondoma microdosing technique adoption is then determined by 'access to information', 'membership of farmer organisation' and 'level of education'.

\section{DISCUSSION}

From the descriptive analysis, the rate of adoption of mineral fertilisation by microdosing was higher among men than women (Table 3 ). This could be explained by the extreme poverty of women and their limited access to extension services, which limits their (technical and financial) ability to adopt agricultural intensification practices (MPF, 2012). In addition, mineral fertilisation by microdosing was more prevalent in the northern part of the country (Zondoma) than in the central east (Kourittenga). The north was a favourite zone for the practice of soil and water conservation techniques like zaï (Sawadogo et al., 2008). This technique which consists on digging sowing pits during the dry season is very well adapted to microdosing.

The analysis of the results of the individual influence of the different explanatory variables indicated that the adoption of mineral fertilisation by microdosing was dependant on a certain number of socio-economic and institutional factors like warrantage, system, access to information through dissemination tools, membership of a farmer organisation and level of education. The influence of variables on mineral fertilisation by microdosing adoption was dependent partly on the study site and the type of farmer.

Access to warrantage. The variable access to warrantage significantly increased the probability of adoption of microdose by women and men in Kourittenga (Table 4). The organisations of farmer in partnership with a lending agency (micro financial institution, $\mathrm{NGO}$, etc.) store their products at harvest in the appropriate warehouses and are issued with cash loans based on the value of their deposit. The loans enable them to address some urgent household financial needs and participate in collective fertiliser purchases. With this credit, farmers are able to carry out some incomegenerating activities (fattening of small ruminants, vegetable gardening and trading) during the off-season.

These results corroborated those of Asfaw and Admassie (2004) that, the greater the availability of credit services, the higher the probability of adopting chemical fertilisers. 
Moreover, authors like Tura et al. (2010), Mbétid-Bessane (2014), Rabe et al. (2017) found a positive influence of credit on the adoption of agricultural innovations in different countries. However, although microdosing technique was a low-cost technology, its implementation required a minimum of financial resources that were still beyond the reach of small farmer.

Access to information. The variable access to information through formal dissemination tools significantly increases the adoption of mineral fertilisation by microdosing by men in Kourittenga. This variable also improved the probability of mineral fertilisation by microdosing adoption by both types of farmers in Zondoma. The determining effect of access to information on the choice of mineral fertilisation by microdosing by women and men in Zondoma was not effective in Kourittenga. It was only relevant in Kourittenga men. This situation could be explained by a greater experience of farmers in the north region in soil fertility management (Ouédraogo, 2005) and by their openness to innovations improving their production conditions than in Kourittenga (Traoré, 2013). To this end, the very precarious production conditions coupled with the multitude of research and development projects on soil fertility management that the Zondoma province has benefited from, were favourable factors for farmers' openness to innovations (Zougmoré et al., 2004).

Farmers, thus needed a minimum of knowledge from extension services to dare to invest in such a context of climate risk. Information on the technical route and the economic benefits of the innovation is very important in the adoption decision. Previous studies highlighted the potential contribution of dissemination tools to the adoption of agricultural innovations (Abadi-Ghadim et al., 2005; Shiferaw et al., 2008; Blazy, 2011; Folefack et al., 2012; Mabah Tene et al., 2013). According to them, the dissemination tools allowed farmers to learn about the characteristics of the technology and the benefits associated with it. The positive effect of access to information on the adoption of chemical fertilisers and improved seed varieties has been demonstrated by Rabe et al. (2017) in Niger.

Level of education. The variable 'level of education' contributed significantly to the adoption of mineral fertilisation by microdosing among Zondoma men (Table 5). This variable improves the farmer's ability to understand agricultural innovation and to perceive the economic benefits of adoption. This result corroborated those of Adéoti et al. (2002) in Benin, Nkamleu and Coulibaly (2000) in Cameroon and Yabi et al. (2016) in Benin, which showed the influence of this variable on the adoption of agricultural innovations. However, the study by Sale et al. (2014) on the analysis of the determinants of adoption of organic manure in Kenya contradicted this theory. These authors found that this variable negatively affects the farmers' decision. In addition, the education level variable did not determine the choice of women in Zondoma. This difference could be explained by the very high illiteracy rate among women (Table 3) which limited the role of this variable in the explanation of their choice.

Membership of farmer organisation. The belonging of Zondoma women to farmer organisation improves their probability of adoption of the microdose (Table 5). Farmer groups constitute the appropriate training and information framework for women. This justified the relevance of the farmer organisation in explaining th e adoption of microdosing in women's. In fact, in the North, women who had hosted microdosing demonstration tests invited members of their organisations to field days. Indeed, this dissemination tool provided better information to farmers as they also brought together researchers and extension agents on the field. Previous authors mentioned that it was within 
farmer organisations that producers shared their experiences and exchanged new technologies (Temple et al., 2011; Mabah Tene et al., 2013). According to these authors, the information collected from farmer organisations played a key role in the adoption process. In sum, farmer groups provide an appropriate training and information framework for women. This is in line with those of Sotamenou (2012) and Yabi et al. (2016) that farmer organisations improve the probability of adoption of agricultural innovations. They play a role of awareness and indisputable training (Sotamenou, 2012).

\section{CONCLUSION}

Microdosing adoption determinants, varied partly according to gender and cropping area. In Kourittenga, warrantage determined the adoption of mineral fertilisation by microdosing by women. In the same area, the determinants of microdosing adoption by men were both access to warrantage and dissemination tools. In Zondoma, access to information and level of education determined adoption among men. Women's adoption was controlled by access to information and membership of a farmer organisation in Zondoma.

Therefore, farmers accompanying with socio-economic and institutional capacitybuilding measures could lead, to improve the adoption of mineral fertilisation by microdosing among poor smallholders in Burkina Faso. These actions would include farmer access to micro-credits and to training in order to improve their economic situation and technical skills. However, micro-credit systems must be adapted to the specificity of the different farmer's categories.

\section{ACKNOWLEDGMENT}

The authors thank the project "Integrated Management of Nutritional Elements for Sustainable Agricultural Production in the Sahel", funded by the International
Development Research Center (IDRC) in collaboration with the Canadian Agency for International Development (CIDA), for financing this study.

\section{REFERENCES}

Abadi-Ghadim, A.K., Pannell, D.J. and Burton, M.P. 2005. Risk, uncertainty, and learning in adoption of a crop innovation. Agricultural Economics 33(1):1-9.

Adéoti, R., Coulibaly, O. and Tamo, M. 2002. Facteurs affectant l'adoption des nouvelles technologies du niébé Vigna unguiculata en Afrique de l'Ouest. Bulletin de la Recherche Agronomique du Bénin 36:1-18.

Asfaw, A. and Admassie, A. 2004. The role of education on the adoption of chemical fertilizer under different socioeconomic environments in Ethiopia. Agricultural Economics 30(3):215-228.

Aune, J.B., Doumbia, M. and Berthé, A. 2007. Microfertilizing sorghum and pearl millet in Mali Agronomic, economic and social feasibility. Agriculture 36(3):199-203.

Bakayogo, M., Maman, N., Palé, S., Sirifi, S., Taonda, S.J.B., Traoré, S. and Mason, S.C. 2011. Microdose and $\mathrm{N}$ and $\mathrm{P}$ fertilizer application rates for pearl millet in West Africa. African Journal of Agricultural Research 6(5):1140-1150.

Blazy, J.M. 2011. De l'innovation à l'adoption de nouvelles pratiques dans la filière banana. Innovations Agronomiques 16:2537.

Batz, F.F., Janssen, W. and Peters, K.J. 2003. Predicting technology adoption to improve research priority setting. Agricultural Economics 28(2):151-164.

Fagbemissi, R.C., Coulibaly, O., Hanna, R. and Endamana, D. 2002. Adoption de variétés de manioc et efficacité durable de la lutte biologique contre l'acarien vert du manioc au Bénin. Bulletin de la Recherche Agronomique du Bénin 38:1-15.

FAO. 2006. World reference base for soil resources 2006. A framework for 
international classiûcation; correlation and communication. Ed. FAO, World Soil Resources Reports $n^{0} 103$, Rome, Italy. $128 \mathrm{pp}$.

FAO. 2011. La pratique de la gestion durable des terres. Directives et bonnes pratiques en Afrique subsaharienne. Terr'Africa, Panorama mondial des approches et technologies de conservation (WOCAT) et Organisation des Nations Unies pour l'alimentation et l'agriculture. http:// www.fao.org/docrep/014/i $1861 \mathrm{f} /$ i1861f00.pdf. Consult 12 September 2017.

Folefack, D.P., Sale, A. and Wakponou, A. 2012. Facteurs affectant l'utilisation de la fumure organique dans les exploitations agricoles en zone sahélienne du Cameroun. Afrique Science: Revue Internationale des Sciences et Technologie 8(2):22-33.

Kam, O. 2013. Les déterminants de l'adoption des innovations culturales en milieu rural : Illustration à partir du cas du Soja introduit par le CNRA (Centre National de Recherche Agronomique) dans la Région Nord de la Côte d'Ivoire. Rev iv hist 22 : 140-156.

Mabah Tene, G.L., Havard, M. and Temple, L. 2013. Déterminants socio-économiques et institutionnels de l'adoption d'innovations techniques concernant la production de maïs à l'ouest du Cameroun. Tropicultura 31(2):137-142.

Mbétid-Bessane, E. 2014. Adoption et intensification du Nouveau Riz pour 1'Afrique en Centrafrique. Tropicultura 32(1):16-21.

MPF. 2012. Document de la politique nationale du genre du Burkina Faso, 2012. http://www.burkinafaso.unfpa.org/ sites/default/files/pub-pdf/Politique Nationale Genre2009.pdf. Consult 8 September 2017.

Nkamleu, G.B. and Coulibaly, O. 2000. Le choix des méthodes de lutte contre les pestes dans les plantations de cacao et de café au Cameroun. Économie Rurale 259:75-85.
Ouattara, B., Somda, B.B., Sermé, I., Traoré, A., Peak, D., Lompo, F., Taonda, S.J.B., Sédogo, M.P. and Bationo, A. 2018. Improving agronomic efficiency of mineral fertilizer through microdose on sorghum in the sub-arid zone of Burkina Faso. In: Improving the profitability, Sustainability and Efûciency of Nutrients Through Site Speciûc Fertilizer Recommendations in West Africa Agro Eco systems. Bationo, A. and al. (Eds.), pp. 241-252. Springer International Publishing, AG.

Ouédraogo, S. 2005. Intensification de l'Agriculture dans le plateau central du Burkina Faso : Une analyse des possibilités à partir des nouvelles technologies. Thèse de Doctorat, Université de Groningen. $317 \mathrm{pp}$.

Ouédraogo, M., Dembelé, Y. and Somé, L. 2010. Perceptions et stratégies d'adaptation aux changements des précipitations : cas des paysans du Burkina Faso. Sécheresse 21(2):87-96.

Palé, S., Mason, S.C. and Taonda, S.J.B. 2009. Water and fertilizer influence on yield of grain sorghum varieties produced in Burkina Faso. South African Journal of Plant and Soil 26(2):91-97.

Ransom, J.H., Paudyal, K. and Adhikari, K. 2003. Adoption of improved maize varieties in the hill of Nepal. Agricultural Economics 29:299-305.

Roesch, M. 2007. Financement et trésorerie des exploitations familiales africaines In: Exploitations agricoles familiales en Afrique de l'Ouest et du Centre. Gafsi, M., Dugué, P., Jamin, J.Y. and Brossier, J. (Eds.), pp. 280-286. Quae, Versailles Cedex.

Rouvière, L. 2008. Régression sur variables catégorielles. Université de Rennes 2. 71pp.

Sale, A., Folefack, D.P., Obwoyere, G.O., Lenah Wati, N., Lendzemo, W.V. and Wakponou, A. 2014. Changements climatiques et déterminants d'adoption de la fumure organique dans la région semi- 
aride de Kibwezi au Kenya. International Journal of Biological and Chemical Sciences 8(2):680-694.

Sawadogo, H., Bock, L., Lacroix, D. and Zombré N.P. 2008. Restauration des potentialités des sols dégradés à l'aide du Zaï et du compost dans le Yatenga (Burkina Faso). Biotechnology, Agronomy, Society and Environment 12(3): 279-290.

Shiferaw, B.A., Kebede, T.A. and You, L. 2008. Technology adoption under seed access constraints and the economic impacts of improved pigeon pea varieties in Tanzania. Agricultural Economics 39(3):309-323.

Sidibé, A. 2005. Farm-level adoption of soil and water conservation techniques in northern Burkina Faso. Agricultural Water Management 71(3):211-224.

Sogodogo, D., Dembélé, O., Konaté, S. and Koumaré, S. 2014. Contribution du warrantage a l'accès des petits producteurs au marché des intrants et des produits agricoles dans les communes rurales de Klela, Fama et Zebala dans la région de Sikasso au Mali. Agronomie Africaine 26 (2):167-179

Sotamenou, J. 2012. Les facteurs d'adoption du compost en agriculture urbaine et périurbaine au Cameroun. Terrains \& Travaux 1(20) :173-187.

Tabo, R., Bationo, A., Gerard, B., Ndjeunga, J., Marchal, D., Amadou, B., Annou, G., Sogodogo, D., Taonda, J.B.S., Hassane, O., Diallo, M.K. and Koala, S. 2007. Improving cereal productivity and farmers' income using a strategic application of fertilizers in West Africa. In: Advances in integrated soil fertility management in SubSaharan Africa: Challenges and opportunities. Bationo, A., Waswa, B., Kihara, J. and Kimetu J. (Eds.). pp. 201208.

Temple, L., Kwa, M., Tetang, J. and Bikoï, A. 2011. Organizational determinants of technological innovation in food agriculture and impacts on sustainable development.
Agronomy for Sustainable Development 31 (4):745-755.

Traoré, A. 2013. Effet de la microdose, des techniques de gestion des eaux et du warrantage sur le revenu des femmes productrices de niébé au Burkina Faso. Mémoire de DEA, Université de Parakou. $79 \mathrm{pp}$.

Traoré, A., Ouattara, B., Sigué, H., Lompo, F. and Bationo, A. 2018. Economic efficiency of sorghum microfertilizing in smallholder Farms in the North-Sudanian zone of Burkina Faso. In: Improving the Profitability, Sustainability and Efficiency of Nutrients Through Site Speciûc Fertilizer Recommendations in West Africa Agro Eco systems. Bationo, A. and al. (Eds.), pp.275286. Springer International Publishing, AG.

Tura, M., Aredo, D., Tsegaye, W., Rovere, R.L., Tesfahun, G., Mwangi, W. and Mwabu, G. 2010. Adoption and continued use of improved maize seeds: Case study of Central Ethiopia. African Journal of Agricultural Research 5(17):2350-2358.

Yabi, J.A., Bachabi, F.X., Labiyi, I.A., Ode, C.A. and Ayena, R.L. 2016. Déterminants socio-économiques de l'adoption des pratiques culturales de gestion de la fertilité des sols utilisées dans la commune de Ouaké au Nord Ouest du Bénin. International Journal of Biological and Chemical Sciences 10(2):779-792.

Zarafi, M.A., Abasse, A.T., Bokar, M., Niang, A. and Traoré, C.O. 2002. Analyse de l'adoption de la régénération naturelle assistée dans la région de Maradi au Niger. In: Deuxième atelier régional sur les aspects socio-économiques de l'agroforesterie au Sahel, Bamako. pp. 17.

Zougmoré, R., Mando, A., Stroosnijder, L. and Ouédraogo, E. 2004. Economic benefits of combining soil and water conservation measures with nutrient management in semiarid Burkina Faso. Nnutrient Cycling in Agroecosystems 70(3):261-269. 